Nat. Hazards Earth Syst. Sci. Discuss., https://doi.org/10.5194/nhess-2018-312

Manuscript under review for journal Nat. Hazards Earth Syst. Sci.

Discussion started: 27 November 2018

(c) Author(s) 2018. CC BY 4.0 License.

(c) (i)

\title{
Perception of the flash flood hazard by the population of Mindelo, $S$. Vicente (Cape Verde)
}

Bruno Martins ${ }^{1}$, Adélia Nunes ${ }^{1}$, Luciano Lourenço ${ }^{1}$, Fátima Castro ${ }^{1}$

${ }^{1}$ Department of Geography and Tourism, CEGOT (Centre of Studies on Geography and Spatial Planning), University of 5 Coimbra, Coimbra, Portugal

Correspondence to: Bruno Martins (bmscmartins@gmail.com)

Abstract. São Vicente Island (Republic of Cape Verde) lies within the Sahelian zone and faces several natural hazards, one of which is the flash flooding hazard. Based on a questionnaire entitled Flash Flood Hazard Perception in Cape Verde applied to 199 subjects, we seek to specifically ascertain some of the factors which influence behavioural decision making to be adopted by populations when confronted with this natural hazard. In order to identify the primary factors associated with the perception of flash flood risk, it was conducted a multivariate technique of the main components analyses (PCA). The results obtained on this study suggest that women present higher levels of knowledge on this type of natural hazard. The study reveals minor statistical differences between the groups with and without prior experience of flash floods concerning perceptions, causal attributions, knowledge and perception of support from public entities regarding flash flood hazard.

15 There is a significant association between causal attributions and the degree of knowledge regarding flash floods hazard, suggesting that the individuals who tend to attribute the phenomenon of flash floods to external factors, evidence adequate knowledge on this type of natural hazard.

\section{Introduction}

The number of disasters related to natural hazards and their impact has significantly increased during the last decades (Armas, 2006; Mata-Lima et al., 2013; Hoeppe, 2016). The resulting economic and social costs, mainly the ones related to losses/damages and the recovery/reconstruction processes are admittedly substantial. Floods hazards, particularly, affect at least 20.000 lives and 20 million people worldwide every year, mostly because of the resulting homelessness (Smith \& Petley, 2009).

25. During the last century, in spite of flash floods having mainly been studied in the context of physical sciences, in 1942, in a seminar about the human reaction to a scenario of flash flood crisis (Human Adjustment to Flood) White acknowledged the important value of human perception in the mitigation process, stressing the human factor as determinant in the risk perception (RP) (Fischhoff, 1995) and risk communication (Bier, 2001; Boholm, 2008). According to Wachinger et al. (2013) risk perception comprises the process of collecting, selecting and interpreting signals about uncertain impacts of events and involves multiple influencing factors in a very complex framework (Fischhoff et al., 1978; Slovic, 1987, 2000; Plapp and Werner, 2006; Wagner, 2007; Fuchs et al., 2017). On the other hand, risk perception depends on the subjective 
Nat. Hazards Earth Syst. Sci. Discuss., https://doi.org/10.5194/nhess-2018-312

Manuscript under review for journal Nat. Hazards Earth Syst. Sci.

Discussion started: 27 November 2018

(c) Author(s) 2018. CC BY 4.0 License.

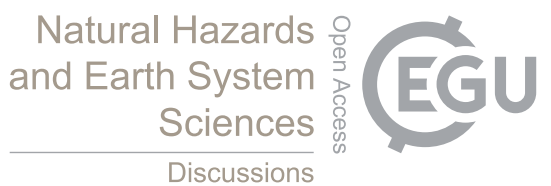

judgement and evaluation of an individual on a specific risk (Renn et al., 1992; Rohrmann and Renn, 2000; Salvati et al., 2014), which can be perceived as potentially dangerous to one person, whilst it may be considered safe to another person.

3. Risk management is, therefore, the modulated mental models and the psychological mechanisms that people use to judge, evaluate, tolerate, and react to risks (Morgan et al., 2001), as well as how individuals and communities perceive the complex

5 and varied factors which interfere in risk perception, such as social networks and capital, media influence, personal experience, values, worldviews and the influences of individual adaptation strategy through learning processes from past events (Dessai et al., 2003; McLeman and Smit, 2006; Bubeck et al., 2012; Collenteur et al., 2015; Rory et al., 2017).

4. Therefore, several researches have focused on the "subjective" component of flood risk and an increasing attention towards perception of flood risk has been recognized as a key element in flood risk management, leading to an ongoing combination

10 of social variables with more conventional risk estimation methods, mainly focusing the Europe and North America areas (Fischhoff, 1995; Renn, 1998; Slovic, 2000; Siegrist and Gutscher, 2006; Soane et al., 2010; Bradford et al., 2012; Bubeck et al., 2012, 2013; Wachinger et al., 2013; Kellens et al., 2013; Birkholz et al., 2014; Salvati et al., 2014;; Babcicky and Seebauer, 2017 Fuchs et al., 2017; Diakakis et al., 2018).

5. In this study we focus on risk perception based on individual characteristics and socioeconomic circumstances, which make

15 people more susceptible to the impact of a hazardous event, in Mindelo- São Vicente, in the archipelago of Cape Verde, where little (or nothing) is known regarding the public perception of the risk posed by flash-floods. Understanding the characteristics of local communities should be, in this context, a priority in order to enhance community resilience during a flash-flood. The theoretical frame of the study is based Psychometric Paradigm (Slovic et al., 1990; Marris et al.,1997; Siegrist et al., 2005) which attempts to quantify individuals' RP and attitudes through survey questionnaire. In the questionnaires respondents are asked to express their perceptions on rating scales (expressed preferences) about various characteristics of the risk (e.g., severity and long-term consequences), their personal ability to cope with the risk (e.g., controllability, knowledge), their feelings (e.g., dread), and their attitudes toward risk management (e.g., trust,). The quantitative ratings try to among specific proactive and passive behaviour groups.

In this research, we seek to specifically ascertain some of the factors which influence behavioural decision making to be

25 adopted by populations when confronted with natural hazards. It is assumed that the acknowledgement that the understanding of these factors will help decision makers to be more aware of which type of variables they must consider in conceptualizing efficient communication strategies to be contemplated in any preventive measures and remediation of natural hazards' plan. Specifically for this study, it was sought to discuss a few issues: (i) how the responders characterize themselves as to perceptions, causal attributions, knowledge degree, as well as perceptions of support by public entities regarding flash floods; (ii) the perceptions, causal attributions, knowledge degree and perception of support by public entities as to flash flood differing regarding variables of socio-demographic characterization of the sample (gender, age, academic qualifications, monthly income, housing type and prior experience with flash floods); (iii) which type of reduction behaviour do the inquired subjects adopt in the face of flash floods. 
Nat. Hazards Earth Syst. Sci. Discuss., https://doi.org/10.5194/nhess-2018-312

Manuscript under review for journal Nat. Hazards Earth Syst. Sci.

Discussion started: 27 November 2018

(c) Author(s) 2018. CC BY 4.0 License.

\section{Geographic context}

The archipelago of Cape Verde is located in the Atlantic Ocean, with latitude situated between parallel $17^{\circ} 12^{\prime}$ and $14^{\circ} 48^{\prime}$ north and longitude which extends from $22^{\circ} 44^{\prime}$ to $25^{\circ} 22^{\prime}$ west of Greenwich. It is composed of ten islands and eight minor islets arrayed in a west-facing horseshoe. The islands are traditionally divided into the Barlavento (windward) group,

5 comprising the islands of Santo Antão, São Vicente, Santa Luzia, São Nicolau, Sal, and Boa Vista, and the Sotavento (leeward) group, comprising Maio, Santiago, Fogo, and Brava.

São Vicente presents a diversified morphology with maximum altitudes to 744 meters in the Monte Verde and 395 meters in Monte Topona. The city of Mindelo is surrounded by slopes that correspond to what remains of the volcano that originated the island and also serves as a limit to the city (fig. 1). Rain is scant and highly variable. In general, rain falls in the form of

10 showers, at times in strong downpours, that can reach values equal to or above monthly mean values. The rainy season occurs between the months of August and October, and may start, at times, in July, associated to the presence of the zone of intertropical convergence, when this is more to the north (Amaral, 1964; Ferreira, 1983).

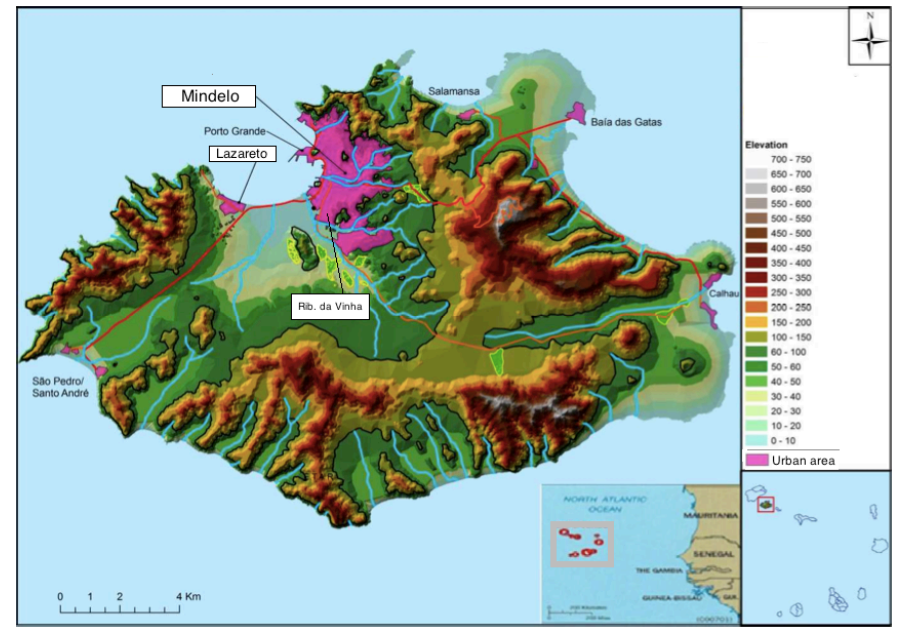

Figure 1: São Vicente and its location in the archipelago of Cape Verde. Source: Adapted from Andrade \& Silva (2017).

15 The average monthly temperature values vary between $22^{\circ} \mathrm{C}$ in the months of January and February and $27^{\circ} \mathrm{C}$ in August and September. These are also the months where the precipitation values are higher. They occur with great intensity. The average annual precipitation value is $51 \mathrm{~mm}$.

São Vicente faces a number of natural hazards particularly flash flooding (PANA, 2004, Martins et al, 2018). The report coordinated by Sílvia Monteiro "Survey of historical data on disasters in Cape Verde 1900-2013" identifies floods as

20 phenomena causing high economic losses. São Vicente is the third island with more registered events. In the period analysed 58 were killed, 138 injured, 14 rescued and 2000 evicted in the archipelago. The report does not indicate deaths in São 
Nat. Hazards Earth Syst. Sci. Discuss., https://doi.org/10.5194/nhess-2018-312

Manuscript under review for journal Nat. Hazards Earth Syst. Sci.

Discussion started: 27 November 2018

(c) Author(s) 2018. CC BY 4.0 License.

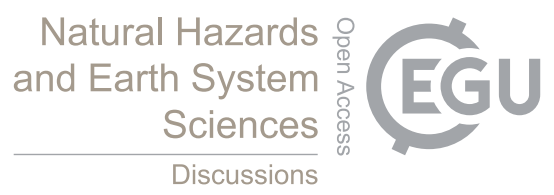

(c) (i)

Vicente but it identifies a large number of displaced persons, suggesting an increase in the frequency of this hazard. This increase is directly related with rapid urban growth that has contributed to the construction of houses, some of which illegal, as well as roads, occupying areas corresponding, many times, to small river beds, dry during most of the year, sometime for years, but that fill rapidly during more intense and prolonged rain. This accelerated construction process is one of the more

5 important key factors in the increase of vulnerability in the face of flash floods (Andrade \& Silva, 2017; Martins et al, 2018). From the point of view of preventing this hazard, measures have to be taken that delay the runoff's response to intense rain, increasing the time of concentration and, therefore, reducing the velocity of the surface runoff. However, the disorganised growth of the city contributed towards the destruction of important drainage channels, built with the intention of channelling the surface waters and also increasing the drainage speed, so it would reach the sea more quickly. Therefore, although the

10 process or physical phenomenon has remained practically unchanged an inadequate response strategy significantly increases the hazard consequences.

\section{Methodology}

For this study it was developed a questionnaire entitled questionnaire on Flash Flood Hazard Perception in Cape Verde applied to 199 subjects. This instrumental methodology is a well-established tool for natural hazard research acquiring information on participant social characteristics, present and past behaviour, standards of behaviour or attitudes and their beliefs and reasons for action with respect to the topic under investigation (Bird, 2009). It also comes in line with Freixo (2009), Pocinho (2012) and Mendes (2015), in which it is defended to exist the need of a quantitative structuring of the field observed results, aiming to define and systematize response configurations and patterns. Considering the proposed goals, this questionnaire comprehended 6 diverse parts (figure 2).

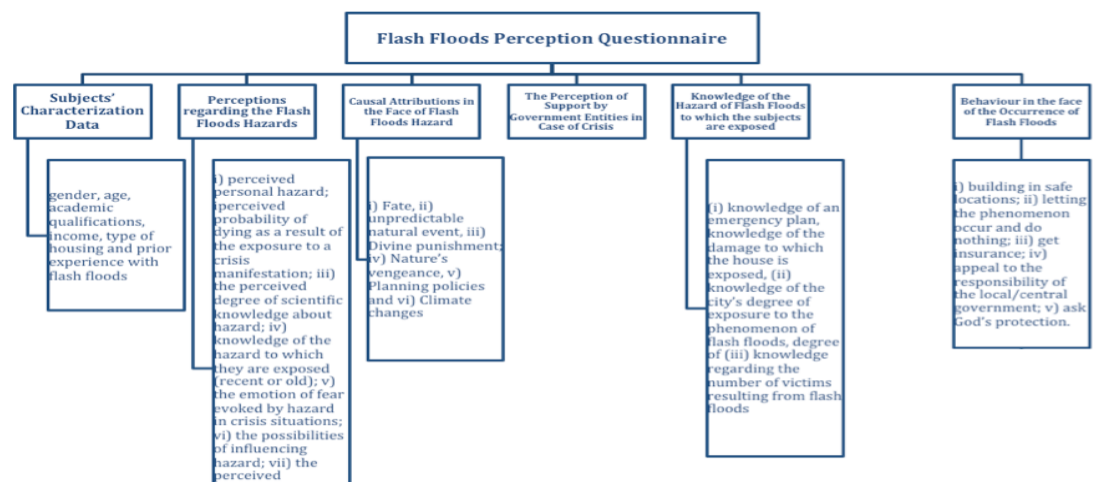


Nat. Hazards Earth Syst. Sci. Discuss., https://doi.org/10.5194/nhess-2018-312

Manuscript under review for journal Nat. Hazards Earth Syst. Sci.

Discussion started: 27 November 2018

(c) Author(s) 2018. CC BY 4.0 License.

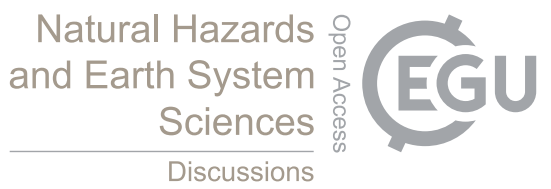

The first part, named Subjects' Characterization Data, comprehends the following data: gender, age, academic qualifications, income, type of housing and prior experience with flash floods.

As for the second part of the questionnaire, named Perceptions regarding the Hazard of Flash Floods, there are 9 questions concerning the characteristics of hazard, rated on a scale of 4 points (from 1-fully disagree to 4-completely agree). Based on

5 the work by Burn (1992), the hazard characteristics comprehended in this questionnaire are: i) perceived personal hazard; ii) perceived probability of dying as a result of the exposure to a crisis manifestation; iii) the perceived degree of scientific knowledge about hazard; iv) knowledge of the hazard to which they are exposed (recent or old); v) the emotion of fear evoked by hazard in crisis situations; vi) the possibilities of influencing hazard; vii) the perceived frequency of crisis; viii) predictability and ix) the future increase or decrease of crisis manifestations. For this dimension we have created an index

10 varying between 1 and 100 points, in which values close to 100 mean that the individuals present adequate perceptions about flash flood hazard.

The third part of this instrument, named Causal Attributions in the Face of Flash Floods Hazard, comprehends 6 questions rated on a 4 points likert type scale (from 1-fully disagree to 4-completely agree). In this section it is requested to the subjects that manifest their degree of agreement regarding the characterization of flash floods: i) Fate, ii) unpredictable natural event, iii) Divine punishment; iv)Nature's vengeance, v) Planning policies and vi) Climate changes. For this dimension we have created an index varying from 1 to 100 points, in which 100 means that the subjects tend to externalize the causes of the phenomenon of flash floods.

The Perception of Support by Government Entities in Case of Crisis constitutes the fourth part of this study's questionnaire. In this section, the subjects have the possibility of addressing the degree of support by government entities (Local and

20 Central Government), from a scale of 4 points (from 1-absence of support to 4-sufficient support). The created index ranges between 1 and 100 points, in which values close to 100 mean that the subjects tend to perceive the support of government entities as sufficient in case of the occurrence of crisis situations.

The fifth part of the questionnaire is named Knowledge of the Hazard of Flash Floods to which the subjects are exposed. Roughly, literature on hazards has enabled to conclude that the knowledge we have on hazards is positively related to the adoption of hazard reduction behaviour. In the questionnaire developed, there are four questions (rated on a 4 points scale from 1-completely disagree to 4-completely agree): knowledge of an emergency plan, knowledge of the damage to which the house is exposed, knowledge of the city's degree of exposure to the phenomenon of flash floods, degree of knowledge regarding the number of victims resulting from flash floods. The index created for this dimension varies between 1 and 100 points, suggesting that values close to 10 mean that the subjects present an accurate knowledge regarding the phenomenon of flash floods.

In the last part of the instrument, named Behaviour in the face of the Occurrence of Flash Floods, the subjects can chose between two of the following behaviours: a) building in safe locations; b) letting the phenomenon occur and do nothing; c) get insurance; d) appeal to the responsibility of the local/central government; e) ask God's protection. According to the type 
Nat. Hazards Earth Syst. Sci. Discuss., https://doi.org/10.5194/nhess-2018-312

Manuscript under review for journal Nat. Hazards Earth Syst. Sci.

Discussion started: 27 November 2018

(c) Author(s) 2018. CC BY 4.0 License.

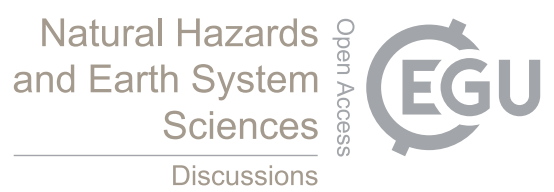

of answer given, the subjects have been arranged into two groups: proactive behaviour versus passive behaviour as to a possible occurrence of flash floods.

The statistical analysis was carried out using IBM SPSS (Version 20.0 for Windows). Analysis of variance (ANOVA) was performed in order to assess whether there were any differences as to the perceptions regarding flash floods hazards, causal

5 attributions, and support by government entities and knowledge about flash floods, considering a set socio-demographic variables. Pearson correlations were also performed in order to identify correlations among the variables analysed. In order to identify the primary factors associated with perception of flash flood risk, a multivariate technique of the principal components analyses (PCA) were performed. The objective of the PCA analysis is to reduce the original number of quality factors and to replace them by new items, called principal components. These components include information about the

10 original factors with the minimal loss of the information. In the first step, a correlation matrix was elaborated to assess possible collinearity among the variables. A correlation coefficient threshold between variables of $|r|>0.7(p<0.05)$ was considered an appropriate indicator for the point where collinearity begins to severely distort model estimation and subsequent prediction (Dormann et al., 2013). In the correlation matrix, there were few pairs of extremely correlated factors, highlighting the high correlations among age, income per capita and education. The Bartlett's test of sphericity and the

15 Kaiser-Meyer-Olkin (KMO) measure were applied for test adequacy of sampling, and the varimax rotation method were performed. The first output results of principal components analysis are the eigenvalues for all identified principal components, which are mutually independent. Thus the factors are ordered according to their contribution to the explanation of the total variance of the quality factor. The useful components are those, where the eigenvalue is higher than one.

\section{Results}

20 3.1 Socio-demographic characterization

This study's sample comprehends 199 subjects residing in Mindelo, S. Vicente (Cape Verde). From the inquired, $37.2 \%$ (74 cases) are male and $62.8 \%$ (125 cases) are female. The age of the inquired varies between 17 and 72 years old (with an age average of 35 years old). Most of the inquired elements claim to have secondary or higher education ( $28.1 \%$ and $29.1 \%$, respectively). The sample elements who cannot read and answer corresponds to $6 \%$, and those with the 1 st and 2nd and 3rd school cycles are $26.1 \%$ and $10.6 \%$, respectively. From the inquired people, $22.1 \%$ earns between 45.36 and 90.71 Euros, $18.6 \%$ claims not to have income, 10.1\% claims to earn between 453.57 and 907.13 Euros and $9 \%$ claims to have an income lower than 45.36 Euros. Around 7 subjects (3.5\%) did not answer this question. When asked as to the type of house, $42.2 \%$ (84 cases) mentioned owning a house. From the inquired residents, $22.1 \%$ (44 cases) mentions living in a rented house and $14.6 \%$ claims living in another situation. Around 42 subjects $(21.1 \%)$ did not answer this question. More than 30 most inquired people (73.4\%) mentions having had past experience with the hazard of flash floods, against $23.1 \%$ (46 cases) who mention not to have had direct contact with the phenomenon of flash floods in the past. Around $3 \%$ of the subjects did not answer this question. 
Nat. Hazards Earth Syst. Sci. Discuss., https://doi.org/10.5194/nhess-2018-312

Manuscript under review for journal Nat. Hazards Earth Syst. Sci.

Discussion started: 27 November 2018

(c) Author(s) 2018. CC BY 4.0 License.

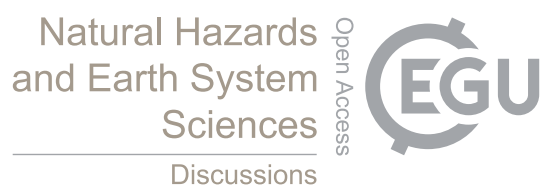

(c) (1)

\begin{tabular}{lll}
\hline Socio-demographic variables & N & $\%$ \\
\hline Gender & 74 & $37.2 \%$ \\
Male & 125 & $62.8 \%$ \\
Female & & \\
& 12 & $6.0 \%$ \\
Education & 62 & $26.1 \%$ \\
Cannot read nor write & 21 & $10.6 \%$ \\
$1^{\text {st }}$ and $2^{\text {nd }}$ cycle & 56 & $28.1 \%$ \\
$3^{\text {d }}$ cycle & 58 & \\
Secondary Education & & \\
Higher Education & 37 & $18.6 \%$ \\
Income & 18 & $9.0 \%$ \\
No income & 44 & $22.1 \%$ \\
$<$ than 5 contos $(€ 45,36)$ & 27 & $13.6 \%$ \\
Between 5 and 10 contos $(€ 45,36$ to $€ 90,71)$ & 30 & $10.1 \%$ \\
Between 10 and 20 contos $(€ 90,71$ to $€ 181,43)$ & 16 & $8.0 \%$ \\
Between 50 and 100 contos $(€ 453,57$ to $€ 907,13)$ & & \\
$>$ than 100 contos $(€ 907,13)$ & 84 & $42.2 \%$ \\
& & $22.1 \%$ \\
Type of House & 44 & $14.6 \%$ \\
Home Ownership & 29 & \\
Rented & & $73.4 \%$ \\
Other Situation & 146 & $23.1 \%$ \\
Prior experience with flash floods & 46 & \\
With experience & & \\
Without experience & &
\end{tabular}

Table 1: Variables of socio-demographic characterization of the sample $(n=199)$.

5

\subsection{Perceptions, causal attributions, knowledge and support from public entities regarding the flash floods hazard}

Considering the average values regarding the Perceptions in the face of Hazard of Flash Floods, it is verified that the subjects have agreed (yet partially) as to the fact that the flash floods in S. Vicente: i) are of high personal hazard ii) are a fatality; iii) raise fear; iv) are not predictable; v) tend to increase in the future. However, the subjects have manifested

10 disagreement as to the fact that flash floods are a phenomenon: i) known by science; ii) old; iii) possibly influenced by human action on its occurrence; iv) whose occurrence is rare (table 2).

As for the Causal attributions in the Face of Flash Floods Hazard, the average values found indicate that the sample subjects revealed to agree as to the fact that flash floods are an unpredictable natural event and result from climate changes. Nevertheless, the sample elements manifest levels of disagreement concerning flash floods being a serious of fate, divine 15 punishment, nature's vengeance and result from inadequate planning policies. 
Nat. Hazards Earth Syst. Sci. Discuss., https://doi.org/10.5194/nhess-2018-312

Manuscript under review for journal Nat. Hazards Earth Syst. Sci.

Discussion started: 27 November 2018

(c) Author(s) 2018. CC BY 4.0 License.

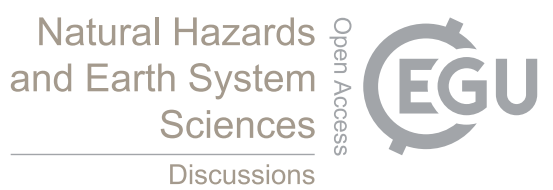

Concerning the Perception of Support from Government Entities in the Case of Flash Floods, the inquired have considered getting insufficient support from the local and central governments.

Regarding the Knowledge of the Flash Floods Hazard, the subjects have disagreed to exist an adequate emergency plan and that their own house is subject to damages; however they have agreed that the city is subject to damages and that human loss

5 can occur (table 2).

\begin{tabular}{|c|c|c|c|c|c|}
\hline Studied variables & Minimum & Maximum & Mean & $\begin{array}{l}\text { Standard } \\
\text { error }\end{array}$ & $\begin{array}{c}\text { Index } \\
\text { (Mean Value) }\end{array}$ \\
\hline $\begin{array}{l}\text { Perceptions in the face of flash floods } \\
\text { Personal hazard } \\
\text { Probably not fatal } \\
\text { Known by science } \\
\text { Ancient hazard } \\
\text { Does not raise fear } \\
\text { Possible influence } \\
\text { Seldom occurs } \\
\text { Predictable }\end{array}$ & $\begin{array}{l}1 \\
1 \\
1 \\
1 \\
1 \\
1 \\
1 \\
1\end{array}$ & $\begin{array}{l}4 \\
4 \\
4 \\
4 \\
4 \\
4 \\
4 \\
4\end{array}$ & $\begin{array}{l}3.30 \\
3.37 \\
2.64 \\
2.56 \\
3.30 \\
2.34 \\
2.59 \\
2.86\end{array}$ & $\begin{array}{l}0.887 \\
0.836 \\
0.931 \\
1.071 \\
1.015 \\
1.138 \\
1.011 \\
1.149\end{array}$ & 63.333 \\
\hline $\begin{array}{l}\text { Causal attributions regarding the flash floods hazard } \\
\text { Twist of fate } \\
\text { Unpredictable natural event } \\
\text { Divine punishment } \\
\text { Nature's vengeance } \\
\text { Planning policies } \\
\text { Climate changes }\end{array}$ & $\begin{array}{l}1 \\
1 \\
1 \\
1 \\
1 \\
1\end{array}$ & $\begin{array}{l}4 \\
4 \\
4 \\
4 \\
4 \\
4\end{array}$ & $\begin{array}{l}2.26 \\
3.15 \\
2.08 \\
2.23 \\
2.18 \\
3.26\end{array}$ & $\begin{array}{l}1.190 \\
1.070 \\
1.147 \\
1.121 \\
0.983 \\
0.876\end{array}$ & 51.329 \\
\hline $\begin{array}{l}\text { Perception of support from government entities in case of } \\
\text { crisis } \\
\text { Support from local government } \\
\text { Support from central government }\end{array}$ & $\begin{array}{l}1 \\
1\end{array}$ & $\begin{array}{l}4 \\
4\end{array}$ & $\begin{array}{l}2.42 \\
2.34\end{array}$ & $\begin{array}{l}0.851 \\
0.914\end{array}$ & 46.785 \\
\hline $\begin{array}{l}\text { Knowledge of the Flash Floods hazard } \\
\text { Proper emergency plan } \\
\text { House subject to damages } \\
\text { City subject to damages } \\
\text { Human loss }\end{array}$ & $\begin{array}{l}1 \\
1 \\
1 \\
1 \\
\end{array}$ & $\begin{array}{l}4 \\
4 \\
4 \\
4\end{array}$ & $\begin{array}{l}2.38 \\
2.52 \\
3.17 \\
3.42 \\
\end{array}$ & $\begin{array}{l}1.073 \\
1.132 \\
0.986 \\
0.960 \\
\end{array}$ & 62.527 \\
\hline
\end{tabular}

Table 3: Descriptive statistics regarding the dimensions on perceptions, causal attributions, knowledge and support from public entities in the face of the flash floods' hazard.

\subsection{Relation between variables}

It is possible to verify a statistically significant association between perceptions regarding of flash floods hazard and causal attributions $(r=0.390 ; p<0.01)$, meaning that the individuals presenting favourable perceptions towards the flash floods hazard tend to attribute the occurrence of flash floods to external factors. It is still possible to conclude the existence between perceptions in the face of the flash floods hazard and the perception of support from public entities $(r=0.221 ; p<0.05)$. Such a

15 result suggests that the individuals who consider having enough support from the public entities present favourable perceptions regarding the phenomenon of flash floods. 
Nat. Hazards Earth Syst. Sci. Discuss., https://doi.org/10.5194/nhess-2018-312

Manuscript under review for journal Nat. Hazards Earth Syst. Sci.

Discussion started: 27 November 2018

(c) Author(s) 2018. CC BY 4.0 License.

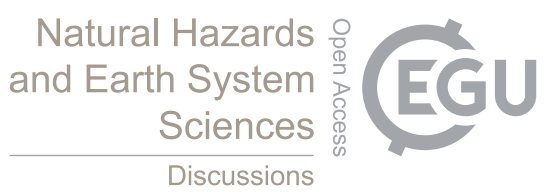

In this study it is still verified a statistically significant association between perceptions in the face of the flash floods hazard and the degree of knowledge by the assessed subjects $(r=0.435 ; \mathrm{p}<0.01)$, suggesting that the individuals with adequate perceptions present an adequate knowledge on this phenomenon. It is still verified a statistically significant association between causal attributions and the hazard perception of support from public entities ( $r=0.187 ; \mathrm{p}<0.001)$, indicating that the

5 subjects with external causal attributions tend to perceive the support from public entities as sufficient in case of crisis. The study's data reveal a statistically significant association between causal attributions and the degree of knowledge towards hazard $(\mathrm{r}=0.182 ; \mathrm{p}<0.05)$, suggesting that the individuals who tend to attribute the phenomenon of flash floods to external factors, evidence proper knowledge on this type of natural hazard.

There is the presence of a statistically significant association between the perception of support from public entities

10 regarding flash floods hazard and the degree of knowledge towards of flash floods hazard $(r=0.157 ; \mathrm{p}<0.05)$, revealing that the subjects who consider having sufficient support from public entities present proper knowledge on the phenomenon of flash floods (table 3).

\begin{tabular}{|c|c|c|c|c|}
\hline & $\begin{array}{l}\text { Perceptions } \\
\text { regarding the } \\
\text { hazard of flash } \\
\text { floods }\end{array}$ & $\begin{array}{l}\text { Causal attributions } \\
\text { regarding the hazard } \\
\text { of flash floods }\end{array}$ & $\begin{array}{l}\text { Perception of the support } \\
\text { from public entities } \\
\text { regarding the hazard of } \\
\text { flash floods }\end{array}$ & $\begin{array}{l}\text { Degree of knowledge } \\
\text { regarding the hazard of } \\
\text { flash floods }\end{array}$ \\
\hline $\begin{array}{l}\text { Perceptions regarding the } \\
\text { hazard of flash floods }\end{array}$ & $-\cdot$ & $0.390^{* *}$ & $0.221^{*}$ & $0.435^{* *}$ \\
\hline $\begin{array}{l}\text { Causal attributions } \\
\text { regarding the hazard of } \\
\text { flash floods }\end{array}$ & $0.390^{* *}$ & $\cdots$ & $0.187^{\circ \star}$ & $0.182^{\circ}$ \\
\hline $\begin{array}{l}\text { Perception of the support } \\
\text { from public entities } \\
\text { regarding the hazard of } \\
\text { flash floods }\end{array}$ & $0.221^{* *}$ & $0.187^{* *}$ & -- & $0.157^{\circ}$ \\
\hline $\begin{array}{l}\text { Degree of knowledge } \\
\text { regarding the hazard of } \\
\text { flash floods }\end{array}$ & $0.435^{\mu *}$ & $0.182^{\star}$ & $0.157^{\star}$ & -. \\
\hline
\end{tabular}

** Significant correlation from 0.01 level (2-tailed) / * Significant correlation from 0.05 (2-tailed)

Table 4: Matrix of correlations (Pearson correlation) for the variables: perceptions, causal attributions, knowledge and support from public entities towards the hazard of flash floods.

There are statistically significant differences between the degree of knowledge regarding the flash floods hazard and the gender variable. Women present higher levels of knowledge regarding the flash floods hazard than men.

However, the analysis of table 4 reveals that the perceptions, causal attributions and perception of support from public

20 entities regarding the flash floods hazard do not differ significantly as to gender. Although there are no statistically significant differences, men present higher percentage numbers regarding perceptions, causal attributions and perception of support from public entities in case of crisis manifestation. 
Nat. Hazards Earth Syst. Sci. Discuss., https://doi.org/10.5194/nhess-2018-312

Manuscript under review for journal Nat. Hazards Earth Syst. Sci.

Discussion started: 27 November 2018

(c) Author(s) 2018. CC BY 4.0 License.

\begin{tabular}{|c|c|c|c|c|c|}
\hline Variables & Gender & $\mathbf{N}$ & Mean & Standard error & $T$ \\
\hline \multirow{2}{*}{$\begin{array}{l}\text { Perceptions regarding the hazard } \\
\text { of flash floods }\end{array}$} & Male & 74 & 65.068 & 15.535 & \multirow[b]{2}{*}{$t(197)=1.148 ; p=0.252$} \\
\hline & Female & 125 & 62.307 & 16.884 & \\
\hline \multirow{2}{*}{$\begin{array}{l}\text { Causal attributions regarding the } \\
\text { hazard of flash floods }\end{array}$} & Male & 74 & 52.507 & 17.991 & \multirow{2}{*}{$t(197)=0.711 ; p=0.478$} \\
\hline & Female & 125 & 50.632 & 17.979 & \\
\hline \multirow{2}{*}{$\begin{array}{l}\text { Perception of the support from } \\
\text { public entities regarding the } \\
\text { hazard of flash floods }\end{array}$} & Male & 71 & 50.035 & 27.606 & \multirow[b]{2}{*}{$\mathrm{t}(189)=1.324 ; \mathrm{p}=0.187$} \\
\hline & Female & 120 & 44.863 & 25.174 & \\
\hline \multirow{2}{*}{$\begin{array}{l}\text { Degree of knowledge regarding } \\
\text { the hazard of flash floods }\end{array}$} & Male & 69 & 55.880 & 20.446 & \multirow{2}{*}{$t(188)=-3.517 ; p=0.001$} \\
\hline & Female & 121 & 66.318 & 19.218 & \\
\hline
\end{tabular}

Table 5: Test for independent samples (gender: male and female) according to variables: perceptions, causal attributions, 5 knowledge and support from public entities regarding the hazard of flash floods.

The analysis of table 5's data reveals the absence of significantly statistical differences between the groups with and without prior experience of flash floods concerning the perceptions, causal attributions, knowledge and perception of support from public entities regarding the flash flood hazard. As to the dimensions mentioned, the subjects with prior experience of flash

10 floods present the higher average values.

\begin{tabular}{lccccc}
\hline \multicolumn{1}{c}{ Variables } & $\begin{array}{c}\text { With/out prior experience } \\
\text { of flash floods }\end{array}$ & $\mathrm{N}$ & Mean & $\begin{array}{c}\text { Standard } \\
\text { error }\end{array}$ & $T$ \\
\hline $\begin{array}{l}\text { Perceptions regarding the of fla } \\
\text { floods hazard }\end{array}$ & With experience & 146 & 64.339 & 16.213 & $\mathrm{t}(190)=1.156 ; \mathrm{p}=0.249$ \\
Causal attributions regarding the & No experience & 46 & 61.101 & 17.652 & $\mathrm{t}(190)=0.901 ; \mathrm{p}=0.064$ \\
flash floods hazard & With experience & 146 & 52.120 & 16.896 & \\
Perception of the support frc & No experience & 46 & 49.424 & 20.037 & \\
public entities in crisis scenario & With experience & 140 & 46.611 & 25.161 & $\mathrm{t}(182)=0.135 ; \mathrm{p}=0.893$ \\
$\begin{array}{l}\text { Degree of knowledge regarding } \mathrm{t} \\
\text { flash floods hazard }\end{array}$ & No experience & 44 & 46.000 & 28.989 & \\
\hline
\end{tabular}

Table 6: Test for independent samples (with/without prior experience of flash floods) according to the variables: perceptions, causal attributions, knowledge and support from public entities according to the flash floods hazard.

15 There are no statistically significant differences between the perceptions, causal attributions, knowledge and perception of support from public entities in a crisis scenario and the age of the inquired subjects (table 6). 
Nat. Hazards Earth Syst. Sci. Discuss., https://doi.org/10.5194/nhess-2018-312

Manuscript under review for journal Nat. Hazards Earth Syst. Sci.

Discussion started: 27 November 2018

(c) Author(s) 2018. CC BY 4.0 License.

\begin{tabular}{|c|c|c|c|c|c|}
\hline \multicolumn{2}{|c|}{ Variables/Age } & \multirow{2}{*}{$\frac{N}{67}$} & \multirow{2}{*}{$\begin{array}{l}\text { Mean } \\
62.29\end{array}$} & \multirow{2}{*}{$\begin{array}{c}\text { Standard erro } \\
14.12\end{array}$} & \multirow[t]{2}{*}{$\mathbf{F}$} \\
\hline Perceptions regarding & Under 25 years old & & & & \\
\hline $\begin{array}{l}\text { the flash floods } \\
\text { hazard }\end{array}$ & $\begin{array}{c}\text { Between } 26 \text { \& } 35 \text { year } \\
\text { old }\end{array}$ & 23 & 59.03 & 15.97 & \\
\hline & $\begin{array}{c}\text { Between } 36 \text { \& } 45 \text { year } \\
\text { old }\end{array}$ & 70 & 65.27 & 17.94 & $\begin{array}{l}F(0.874) \\
p=0.480\end{array}$ \\
\hline & $\begin{array}{c}\text { Between } 46 \text { \& } 55 \text { year } \\
\text { old }\end{array}$ & 28 & 65.43 & 17.18 & \\
\hline & Over 55 years old & 11 & 61.00 & 18.50 & \\
\hline \multirow{5}{*}{$\begin{array}{l}\text { Causal attributions } \\
\text { regarding the flash } \\
\text { floods hazard }\end{array}$} & Under 25 years old & 67 & 48.78 & 18.96 & \multirow{5}{*}{$\begin{array}{l}F(0.363) \\
p=1.090\end{array}$} \\
\hline & $\begin{array}{c}\text { Between } 26 \text { \& } 35 \text { year } \\
\text { old }\end{array}$ & 23 & 50.74 & 20.21 & \\
\hline & $\begin{array}{c}\text { Between } 36 \text { \& } 45 \text { year } \\
\text { old }\end{array}$ & 70 & 54.27 & 17.20 & \\
\hline & $\begin{array}{c}\text { Between } 46 \text { \& } 55 \text { year } \\
\text { old }\end{array}$ & 28 & 48.93 & 14.81 & \\
\hline & Over 55 years old & 11 & 55.50 & 18.48 & \\
\hline \multirow{5}{*}{$\begin{array}{l}\text { Perception of the } \\
\text { support from public } \\
\text { entities in crisis } \\
\text { scenario }\end{array}$} & Under 25 years old & 65 & 43.90 & 20.30 & \multirow{5}{*}{$\begin{array}{l}F(0.132) \\
p=1.794\end{array}$} \\
\hline & $\begin{array}{l}\text { Between } 26 \text { \& } 35 \text { year } \\
\text { old }\end{array}$ & 23 & 39.74 & 29.69 & \\
\hline & $\begin{array}{c}\text { Between } 36 \text { \& } 45 \text { year } \\
\text { old }\end{array}$ & 65 & 51.01 & 28.12 & \\
\hline & $\begin{array}{c}\text { Between } 46 \text { \& } 55 \text { year } \\
\text { old }\end{array}$ & 28 & 44.61 & 25.88 & \\
\hline & Over 55 years old & 10 & 60.40 & 34.08 & \\
\hline \multirow{5}{*}{$\begin{array}{l}\text { Degree of knowledge } \\
\text { regarding the hazard } \\
\text { of flash floods }\end{array}$} & Under 25 years old & 65 & 62.81 & 18.80 & \multirow{5}{*}{$\begin{array}{l}F(0.594) \\
p=0.699\end{array}$} \\
\hline & $\begin{array}{c}\text { Between } 26 \text { \& } 35 \text { year } \\
\text { old }\end{array}$ & 22 & 63,25 & 21.11 & \\
\hline & $\begin{array}{c}\text { Between } 36 \& 45 \text { year } \\
\text { old }\end{array}$ & 66 & 64.50 & 21.41 & \\
\hline & $\begin{array}{c}\text { Between } 46 \text { \& } 55 \text { year } \\
\text { old }\end{array}$ & 26 & 59.38 & 19.23 & \\
\hline & Over 55 years old & 11 & 55.00 & 23.15 & \\
\hline
\end{tabular}

Table 7: One Way Anova test for the variables: perceptions, causal attributions, knowledge and support from the public regarding the flash floods hazard according to age.

5

The analysis of table 7 also reveals absence of statistically significant differences between the perceptions the causal attributions, the knowledge and the perception of support from public entities in a crisis scenario of flash floods and the academic qualifications.

A global analysis of the previous table's data reveals that the subjects with the higher school levels tend to present more

10 adequate perceptions, a higher degree of knowledge, the perception that the support from public entities in a crisis scenario is sufficient and causal attributions are externalized. 
Nat. Hazards Earth Syst. Sci. Discuss., https://doi.org/10.5194/nhess-2018-312

Manuscript under review for journal Nat. Hazards Earth Syst. Sci.

Discussion started: 27 November 2018

(c) Author(s) 2018. CC BY 4.0 License.

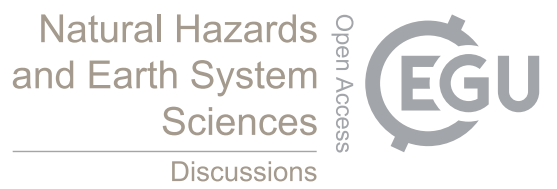

(c) (1)

\begin{tabular}{|c|c|c|c|c|c|}
\hline \multicolumn{2}{|c|}{ Variables/ Schooling } & \multirow{2}{*}{$\begin{array}{l}N \\
12\end{array}$} & \multirow{2}{*}{$\begin{array}{c}\text { Mean } \\
59.667\end{array}$} & \multirow{2}{*}{$\begin{array}{c}\text { Standard error } \\
18,031\end{array}$} & \multirow[t]{2}{*}{$F$} \\
\hline Perceptions regarding the & Cannot read nor write & & & & \\
\hline hazard of flash floods & $1^{\text {st }}$ and $2^{\text {nd }}$ cycle & 52 & 61.430 & 18,928 & \\
\hline & $3^{\text {rd }}$ cycle & 21 & 64.032 & 14,603 & $\begin{array}{l}F(1.885) \\
p=0.115\end{array}$ \\
\hline & Secondary Education & 56 & 60.780 & 14,345 & \\
\hline & Higher Education & 58 & 68.012 & 15,614 & \\
\hline \multirow{5}{*}{$\begin{array}{l}\text { Causal attributions } \\
\text { regarding the hazard of } \\
\text { flash floods }\end{array}$} & Cannot read nor write & 12 & 45.917 & 19,457 & \multirow{5}{*}{$\begin{array}{l}F(0.231) \\
p=0.299\end{array}$} \\
\hline & $1^{\text {st }}$ and $2^{\text {nd }}$ cycle & 52 & 52.721 & 17,092 & \\
\hline & $3^{\text {rd }}$ cycle & 21 & 44.738 & 12,837 & \\
\hline & Secondary Education & 56 & 53.250 & 19,254 & \\
\hline & Higher Education & 58 & 51.733 & 18,517 & \\
\hline \multirow{5}{*}{$\begin{array}{l}\text { Perception of the support } \\
\text { from public entities in } \\
\text { crisis scenario }\end{array}$} & Cannot read nor write & 11 & 53.500 & 37,494 & \multirow{5}{*}{$\begin{array}{l}F(1.185) \\
p=0.319\end{array}$} \\
\hline & $1^{\text {st }}$ and $2^{\text {nd }}$ cycle & 48 & 42.594 & 27,650 & \\
\hline & $3^{\text {rd }}$ cycle & 20 & 44.725 & 21,596 & \\
\hline & Secondary Education & 55 & 44.500 & 21,854 & \\
\hline & Higher Education & 57 & 51.947 & 27,412 & \\
\hline \multirow{5}{*}{$\begin{array}{l}\text { Degree of knowledge } \\
\text { regarding the hazard of } \\
\text { flash floods }\end{array}$} & Cannot read nor write & 12 & 53.250 & 26,636 & \multirow{5}{*}{$\begin{array}{l}F(1.033) \\
p=0.392\end{array}$} \\
\hline & $1^{\text {st }}$ and $2^{\text {nd }}$ cycle & 48 & 65.109 & 20,998 & \\
\hline & $3^{\text {rd }}$ cycle & 20 & 64.113 & 14,728 & \\
\hline & Secondary Education & 55 & 60.550 & 19,425 & \\
\hline & Higher Education & 55 & 63.700 & 20,55460 & \\
\hline
\end{tabular}

Table 8: One Way Anova test for the variables: perceptions, causal attributions, knowledge and support from the public entities regarding the flash floods hazard according to education.

5 The results of factor analysis shows a Bartlett's test of sphericity with $P<0.001$ and the Kaiser-Meyer-Olkin (KMO) measure of 0.811 , indicating the sampling is adequate. The results of PCA (Tables 9 and 10), which covered 60 percent of the variance in the first four axes, are determined for the first two as 44.8 percent of the total variability.

\begin{tabular}{cccc}
\hline Component number & Eigenvalue & \% of Variance & Cumulative \% \\
\hline 1 & 7.236 & 31.462 & 31.462 \\
2 & 3.072 & 13.356 & 44.817 \\
3 & 1.835 & 7.978 & 52.796 \\
4 & 1.691 & 7.351 & 60.147 \\
\hline
\end{tabular}

(Extraction method: Principal component analysis)

Table 9: Total variance explained. 
Nat. Hazards Earth Syst. Sci. Discuss., https://doi.org/10.5194/nhess-2018-312

Manuscript under review for journal Nat. Hazards Earth Syst. Sci.

Discussion started: 27 November 2018

(c) Author(s) 2018. CC BY 4.0 License.

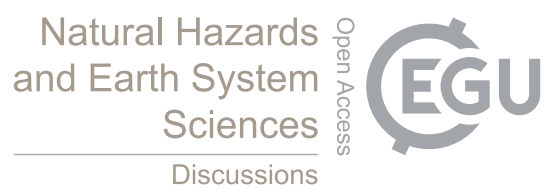

(c) (i)

Axis 1 shows the relation typified by education and the notorious disagreement concerning flash floods since they are perceived as a risk known and predictable by science but the causes are mainly related with a divine and nature's punishment and result from inadequate planning policies applied to the territory.

Axis 2, which explains $13 \%$ of the variance, shows the negative opposition between gender and the perception of support

5 from public entities before and during a crisis scenario, namely the planning policies, proper emergency plans and support from local and central government. Components 3 and 4 explain about 15 percent of the total variance observed. Axis 3 relates the prior experience with flash flood with economic damages and human losses whilst axis 4 focuses on the causality of flash floods considering it as a twist of fate, an unpredictable event that are related with climate changes.

\begin{tabular}{|c|c|c|c|c|}
\hline Parameters & $\begin{array}{c}\text { Component } \\
1 \\
\end{array}$ & $\begin{array}{c}\text { Component } \\
2 \\
\end{array}$ & $\begin{array}{c}\text { Component } \\
3 \\
\end{array}$ & $\begin{array}{c}\text { Component } \\
4 \\
\end{array}$ \\
\hline Education & 0.867 & & & \\
\hline Gender & & -0.657 & & \\
\hline \multicolumn{5}{|l|}{ Type of House } \\
\hline Prior experience with flash floods & & & -0.693 & \\
\hline Personal hazard & & & 0.533 & \\
\hline Probably not fatal & & 0.506 & & \\
\hline Known by science & 0.725 & & & \\
\hline Ancient hazard & -0.638 & & & \\
\hline Does not raise fear & & & & 0.848 \\
\hline \multicolumn{5}{|l|}{ Possible influence } \\
\hline Predictable & 0.819 & & & \\
\hline Twist of fate & & & & 0.501 \\
\hline Unpredictable natural event & & & & 0.808 \\
\hline Divine punishment & 0.818 & & & \\
\hline Nature's vengeance & 0.726 & & & \\
\hline Planning policies & 0.596 & 0.549 & & \\
\hline Climate change & & & & 0.769 \\
\hline Support from local government & & 0.683 & & \\
\hline Support from central government & & 0.699 & & \\
\hline Proper emergency plan & & 0.769 & & \\
\hline House subject to damages & & & 0.531 & \\
\hline City subject to damages & & & 0.835 & \\
\hline Human loss & & & 0,850 & 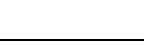 \\
\hline
\end{tabular}


Nat. Hazards Earth Syst. Sci. Discuss., https://doi.org/10.5194/nhess-2018-312

Manuscript under review for journal Nat. Hazards Earth Syst. Sci.

Discussion started: 27 November 2018

(c) Author(s) 2018. CC BY 4.0 License.

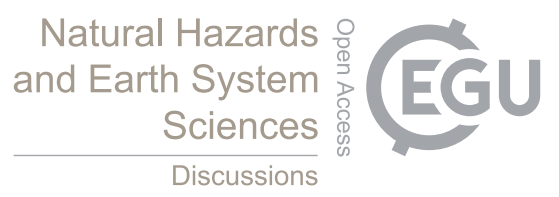

\section{Discussion}

Several authors (Botzen et al., 2009; Slovic, 2010; Kellens et al., 2013; Salvati et al., 2014; Bradford et al., 2012; Fuchs et al., 2017) consider in almost every study on flood-risk perception that socio-demographic characteristics are examined and the most important characteristics seem to be age, gender, education level, income, home ownership, as well as direct

5 experience of floods in previous years. As in our study age and income are well related with education (r: $-0.755 ; \mathrm{r}: 0.824$, respectively), meaning that are the younger and the higher school levels people that recorded the highest level of income. Thus, regarding education, higher-educated people usually show higher levels of RP (Sims \& Baumann, 1983; Wilson, 1990; Ho et al., 2008; Armas \& Avram, 2009; Bradford et al., 2012). Ho et al. (2009) suggest that people with more years of education may acquire and understand new information more easily. As a result, they may be aware of more mitigation

10 actions from local governments and experts and thus may feel a higher degree of controllability over a disaster. Lopez Marrero and Yarnal (2010) identify a positive association between income and housing conditions (construction materials) and housing location, as people with lower incomes will predominantly reside in poorer housing conditions in less favourable areas (e.g., flood-prone areas). Conversely, other authors (Slovic, 2010; Pagneux et al., 2011; Poortinga et al., 2011) found no relationship between perceived risk and educational level and income.

15 Gender is strongly related to risk judgments and attitudes (Slovic, 2010). Several studies (Ho et al., 2009; Lindell et al., 2010) found that men have, on average, lower perceived levels of flood risks than women, although Botzen (2009) suggests an opposite relation. The results obtained on this study suggests that women present higher levels of knowledge, which can be related with biological and social factors; more concerned about human health and (Steger and Witt, 1989) or because they have been characterized as physically more vulnerable to risks (Riger et al., 1978).

20 No significant statistical differences between the groups with and without prior experience of flash floods have found concerning the perceptions, causal attributions, knowledge and perception of support from public entities regarding flash flood hazard. The subjects with prior experience of flash floods tend to acknowledge hazard and are aware of the need to protect from it (Burn, 1999), perceive hazards as being more frequent and see themselves as future victims, increasing the motivation to involve in hazard reduction behaviours (Weinstein, 1989; Plapp \& Werner, 2006, Miceli et al., 2008, Terpstra, 2009). The minor statistical differences between the groups could be related as to not resulting solely from individual interactions, but also from collective representations, which derive from experiences and community interpretations, as well as representations associated to territory (Mendes, 2015; Monteiro et al., 2015). Several studies concluded that perceived likelihood of an event and perceived or experienced frequency of hazardous events are factors that do not play a very important role in the RP of natural hazards (Heitz et al, 2009).

30 In our study, the poorer perception seems to be related to the causal attributions regarding flash floods hazard, mainly attributed to the external cause such as divine punishment or nature's vengeance. For several authors (Tierney, 1999; Weichselgartner, 2001; Johnson et al., 2004) hazards and risks are socially constructed and then complexly connected with the dynamics of the social system - culture, institutions, values, beliefs, etc. In Cape Verde Islands, as in other similar 
Nat. Hazards Earth Syst. Sci. Discuss., https://doi.org/10.5194/nhess-2018-312

Manuscript under review for journal Nat. Hazards Earth Syst. Sci.

Discussion started: 27 November 2018

(c) Author(s) 2018. CC BY 4.0 License.

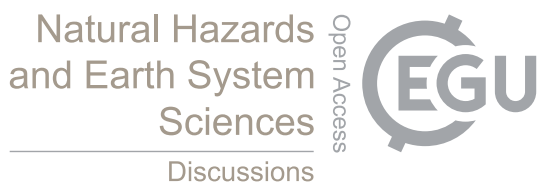

societies in developing country, most of the people have local spiritual beliefs that pervade their everyday activities and are commonly used to rationalize various incidents and observations (Schumm, 1994; Byg and Salick 2009; Lata and Nunn, 2012). In this context, the problem is specially that if a person believes a phenomenon to have a divine cause then not only is it purposeless to try and change it but it is also an offend to the divinity to contemplate doing (Lata and Nunn, 2012).

5 Because risk perception does not occur in a social vacuum one cannot account for how people perceive and understand risks without also considering the social contexts (Oltedal et al., 2004). In this sense, Douglas (1978) consider that risk perception it is a socially, or culturally, constructed phenomenon, however also governed by personality traits, needs, preferences, or properties of the risk objects. Both perspectives need to be integrated into the formal decision-making process. What is perceived as dangerous, and how much risk to accept, is a function of one's cultural adherence and social learning.

10 Therefore, strategies for eliciting optimal responses to such risk emphasize the effective risk communication grounded in an appropriate sociocultural context (Leiserowitz, 2006). Consequently, knowledge about which aspects or characteristics of the risk source which is important for subjective risk judgements may influence such demands and hence also political actions aimed at reducing the risk.

\section{Conclusion, limitations and further research}

15 Risk perception is intrinsically subjective and represents a combination of science and judgment with significant social, cultural, psychological, and political factors. The age, race, gender and education differences in perceptions and attitudes point towards the role of status, power, alienation, trust, perceived government responsiveness, and other socio-political factors in determining perception and acceptance of risk. In this perspective, flood-risk perception is a complex process that encompasses both cognitive (e.g., likelihood, knowledge, etc.) and affective (e.g., feelings, beliefs, perceived control, etc.) features, wherein local conditions have a major effect on people's knowledge and behaviour. As a result, approaches and methods applied in the field are often very heterogeneous, which makes results from different studies difficult to compare, and can justify why some results don't seem to agree each other or even appear to be inconsistent with each other.

In our study, we believe that although some predictors were found based in the used model, explained variance were relatively low, indicating noise or the presence of other, non-measured confounding variables. Thus, in order to reduce the ambiguity and complexity of risk perception and define theoretical concepts of risk more research is needed. However, the gathered results presented here can help flood managers in the developments of national and local flood risk management strategies, as well as preparing risk communication, which integrate the complexity of individual/cultural risk perceptions. Define clear strategies in flood-risk people's behaviour is a priority. To elaborate educational programs on flash-flood risks, which could be accomplished through training sessions, presentations at public functions, informational fliers, and other sources of communication, that focus on understanding flood causes and possible consequences, increasing awareness of warning sources, and informing the public about available tools and data it's essential. 
Nat. Hazards Earth Syst. Sci. Discuss., https://doi.org/10.5194/nhess-2018-312

Manuscript under review for journal Nat. Hazards Earth Syst. Sci.

Discussion started: 27 November 2018

(c) Author(s) 2018. CC BY 4.0 License.

\section{Acknowledgment}

This work was supported by the European Regional Development Funds, through the COMPETE 2020 - Operational

5 Programme 'Competitiveness and Internationalization', under Grant POCI-01-0145- FEDER-006891; and by National Funds through the Portuguese Foundation for Science and Technology (FCT) under Grant UID/GEO/04084/2013.

\section{References}

1. Amaral, I.: Santiago de Cape Verde. A Terra e os Homens. Lisboa, Junta de Investigações do Ultramar, 444 p., (Memórias, 2nd series; 48), 1964.

2. Andrade, D. \& Silva, J.: Contributos para uma estrutura de ordenamento da cidade-ilha de Mindelo-S. Vicente (Contributions to a spatial planning structure of the city-island of Mindelo-S. Vicente), GOT, 11 - Revista de Geografia e Ordenamento do Território, 2017.

3. Armas, I., Avram, E.: Perception of flood risk in Danube Delta, Romania. Natural Hazards, 50 (2):269-287, 2009.

4. Armas, I.: Earthquake hazard perception in Bucharest, Romania. Risk Anal 26(5):1223-1234, 2006.

5. Babcicky P. \& Seebauer S.: The two faces of social capital in private flood mitigation: opposing effects on risk perception, self-efficacy and coping capacity, Journal of Risk Research, 20, (8), 1017-1037, 2017.

6. Bier, M.: On the state of the art: risk communication to the public, Reliability Engineering \& System Safety, 71 (2), 139-150, 2001.

7. Birkholz, S., Muro M., Jeffrey P., Smith, H.: Rethinking the relationship between flood risk perception and flood management. The Science of the total environment, 478, 12-20, 2014.

8. Boholm, A.: New perspectives on risk communication: uncertainty in a complex society. Journal of Risk Research, $11(1-2): 1-3,2008$.

9. Botzen, W., Aerts, J., Bergh, J.: Willingness of homeowners to mitigate climate risk through insurance. Ecological Economics, 68 (8-9): 2265-2277, 2009.

10. Bradford, R., O'Sullivan, J., van der Craats, I., Krywkow, J., Rotko, P., Aaltonen, J., Bonaiuto, M., De Dominicis, S., Waylen, K., Schelfaut, K.: Risk perception - issues for flood management in Europe, Nat. Hazards Earth Syst. Sci., 12, 2299-2309. https://doi.org/10.5194/nhess-12-2299-2012, 2012.

11. Bruen, M., Gebre, F.: Worldwide public perception of flood risk in urban areas and it's consequences for hydrological design in Ireland, National Hydrology Seminar, 2001.

12. Bubeck, P., Botzen, W., Kreibich, H., Aerts, J.: Detailed insights into the influence of flood-coping appraisals on mitigation behaviour, Global Environmental Change, 23, 5, p. 1327-1338, 2013. 
Nat. Hazards Earth Syst. Sci. Discuss., https://doi.org/10.5194/nhess-2018-312

Manuscript under review for journal Nat. Hazards Earth Syst. Sci.

Discussion started: 27 November 2018

(c) Author(s) 2018. CC BY 4.0 License.

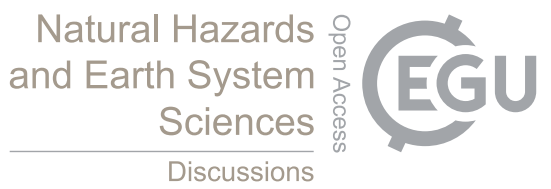

13. Bubeck, P., Botzen, W., Aerts, J.: A Review of Risk Perceptions and Other Factors that Influence Flood Mitigation Behavior. Risk Analysis, 32: 1481-1495, 2012.

14. Burn, D.: Perceptions of flood risk: A case study of the Red River Flood of 1997, Water Resour. Res., 35(11), 3451-3458, 1999.

5

15. Burton, I.; Kates, A.; White, G.: The Environment as Hazard, Guildford Press, London, 1993.

16. Byga, A., Salick, J.: Local perspectives on a global phenomenon - Climate change in Eastern Tibetan villages. Global Environmental Change 19, 156-166, 2009.

17. Collenteur, R., de Moel, H., Jongman, B., Di Baldassarre, G.: The failed-levee effect: do societies learn from flood disasters?, Nat. Hazards, 76, 373-388, 2015.

18. Dessai, S., Adger, W., Hulme, M., Koehler, J., Turnpenny, J., Warren, R., Köhler, J.: Defining and experiencing dangerous climate change defining and experiencing dangerous climate change, Climatic Change, Vol. 64 Nos 1/2, 11-25, 2003.

19. Diakakis, M., Priskos G., Skordoulis, M.: Public perception of flood risk in flash flood prone areas of Eastern Mediterranean: The case of Attica Region in Greece. International Journal of Disaster Risk Reduction, 28, 404-413, 2018.

20. Dixit, A.: Floods and vulnerability: need to rethink flood management, Natural Hazards. vol. 28, pp. 155-179, 2003.

21. Dormann, C., Elith, J., Bacher, S., Buchmann, C., Carl, G., Carré, G., Marquéz, J., Gruber, B., Lafourcade, B., Leitão, P., Münkemüller, T., McClean, C., Osborne, P., Reineking, B., Schröder, B., Skidmore, A., Zurell, D., Lautenbach, S.: Collinearity: a review of methods to deal with it and a simulation study evaluating their performance. Ecography 36, 27-46. 2013.

22. Douglas, M.: Cultural Bias, Occasional Paper n.35, Royal Anthropological Institute of Great Britain and Ireland. 1978.

23. Ferreira, D.: Étude de la convection au-dessus de l'atlantique tropical au large de 1'Afrique occidental. Linha de acção de Geografia Física, Relatório nº16, Lisbon, CEG, INIC, 37 p., 1983.

24. Fischhoff, B.: Risk Perception and Communication Unplugged: Twenty Years of Process. Risk Analysis, 15: 137$145,1995$.

25. Fischhoff, B., Slovic, P., Lichtenstein, S., Read, S., Combs, B.: How safe is safe enough? A psychometric study of attitudes towards technological risks and benefits. Policy Sciences, 9 (2), 127-152, 1978.

26. Fordham, M.: The place of gender in earthquake vulnerability and mitigation. In Second Euro Conference on Global Change and Catastrophic Risk Management - Earthquake Risks in Europe, Austria, Luxemburg, Austria, 2000.

27. Freixo, M.: Metodologia científica. Fundamentos, métodos e técnicas. Lisboa: Instituto Piaget, 2009. 
Nat. Hazards Earth Syst. Sci. Discuss., https://doi.org/10.5194/nhess-2018-312

Manuscript under review for journal Nat. Hazards Earth Syst. Sci.

Discussion started: 27 November 2018

(c) Author(s) 2018. CC BY 4.0 License.

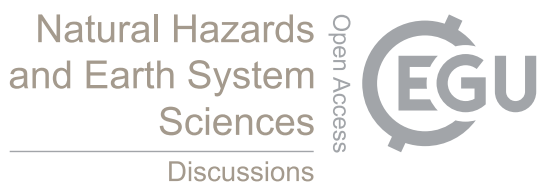

28. Fuchs, S., Karagiorgos, K., Kitikidou, K., Maris, F., Paparrizos, S., Thaler, T.: Flood risk perception and adaptation capacity: a contribution to the socio-hydrology debate, Hydrol. Earth Syst. Sci., 21, 3183-3198, https://doi.org/10.5194/hess-21-3183-2017, 2017.

29. Heitz, C., Spaeter, S., Auzet, A., Glatron, S.: Local stakeholders' perception of muddy flood risk and implications

5 for management approaches: A case study in Alsace (France). Land Use Policy, 26:443-451, 2009.

30. Ho, M., Shaw, D., Lin, S., Chiu, Y.: How do disaster characteristics influence risk perception? Risk Analysis, 28 (3):635-643, 2008.

31. Hoeppe, P.: Trends in weather related disasters - Consequences for insurers and society. Weather and Climate Extremes,11, 70-79, 2016.

32. Johnson J., Wilke, A., Weber E.: Beyond a trait view of risk-taking: a domain- specific scale measuring risk perceptions, expected benefits, and perceived-risk attitude in German-speaking populations, Pol. Psychol Bull, 35:153-72, 2004.

33. Kaplan, S.: The urban forest as a source of psychological well-being. In G. A. Bradley, Ed., Urban Forest Landscapes: Integrating multidisciplinary perspectives. Seattle: University of Washington Press, 1995.

34. Kellens, W., Terpstra, T., Schelfaut, K., De Maeyer, P.: Perception and communication of flood risks: A literature review. Risk Analysis. 33 (1), 24-49, 2013.

35. Kruszewski, A. \& Madj, P.: Local flood Warning Systems in Poland - Plans and implementation Problems, Paper presented at the "Southern Association of ALERT Systems 12th Coference \& Exposition. Denver, Colorado, October, 24-27 p., 2000.

Lindell, M. \& Hwang, S.: Households' perceived personal risk and responses in a multihazard environment. Risk Analysis, 28 (2), 539-556.p, 2008

39. Lindell, M. \& Whitney, D.: Correlates of household seismic hazard adjustment adoption, Risk Analyses, no.20, 1325 p., 2000.

40. Lopez, T., Yarnal, B.: Putting adaptive capacity into the context of people's lives: a case study of two flood-prone communities in Puerto Rico. Natural Hazards, 52 (2): 277-297 p., 2010.

41. López-Marrero, T. \& Yarnal, B.: Putting adaptive capacity into the context of people's lives: a case study of two flood-prone communities in Puerto Rico, Nat Hazards 52(2): 277-297 277, 2010.

42. Marris, C., Langford, I., Saunderson, T., O'Riordan, T.: Exploring the "psychometric paradigm": comparisons between aggregate and individual analyses, Risk Anal. 17(3):303-12, 1997. 
Nat. Hazards Earth Syst. Sci. Discuss., https://doi.org/10.5194/nhess-2018-312

Manuscript under review for journal Nat. Hazards Earth Syst. Sci.

Discussion started: 27 November 2018

(c) Author(s) 2018. CC BY 4.0 License.

(c) (i)

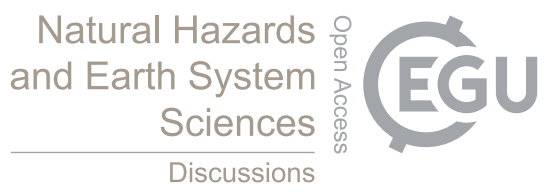

43. Martins, B., Lourenço, L., Monteiro, S.: Natural hazards in São Vicente (Cape Verde), Journal of Environmental Geography 11(1-2):1-8, 2018. DOI: 10.2478/jengeo-2018-0001

44. Mata-Lima, H., Alvino-Borba, A., Pinheiro, A., Mata-Lima, A., Almeida, J.: Impacts of natural disasters on environmental and socio-economic systems: what makes the difference?, Ambiente \& Sociedade, 16(3), 45-64,

5 2013.

45. McCaffrey: Thinking of wildfire as a natural hazard. Society and Natural Resources, 17(6), 509-516 p., 2004.

46. McGee \& Russell: "It's just a natural way of life...": An investigation of wildfire preparedness in rural Australia, Environmental Hazards, 5(1), 1-12 p., 2003.

47. Mcleman, R. \& Smit, B.: Vulnerability to climate change hazards and risks: crop and flood insurance. Canadian Geographer / Le Géographe canadien, 50: 217-226, 2016.

48. Mendes, J.: Sociologia do Risco. Uma breve introdução e algumas lições. Coimbra: University of Coimbra Press, 2015.

49. Miceli, R., Sotgiu, I., Settanni, M.: Disaster Preparedness and Perception of Flood Risk: A study in an Alpine Valley in Italy. Journal of Environmental Psychology, 28, 164-173 p., 2008.

50. Monteiro, A., Cardozo, C., Lopes, E.: Sentidos Territoriais: a paisagem como mediação em novas abordagens metodológicas para os estudos integrados em riscos de desastres. In: Siqueira, A., Valêncio, N., Siena, M., Malagoli, M.: (Org.). Riscos de desastres relacionados à água. São Paulo: RiMa, 2015.

51. Morgan, M., Fischhoff, B., Bostrom, A.: Risk communication: The mental models approach. Cambridge University Press, New York, 2001.

52. Oltedal, S., Moen, B., Klempe, H., Rundmo, T.: Explaining risk perception. An evaluation of cultural theory. c Rotunde publikasjoner Rotunde no. 85, Editor: Torbjørn Rundmo Norwegian University of Science and Technology, Department of Psychology, 2004.

53. Pagneux, E., Gísladóttir, G., Jónsdóttir, S.: Public perception of flood hazard and flood risk in Iceland: A case study in a watershed prone to ice-jam floods, Nat. Hazards, 58, 269-287, 2011.

54. Plapp, T. \& Werner, U.: Understanding risk perception from natural hazards: examples from Germany. In: RISK 21 Coping with risks due to natural hazards in the 21 st century. W. Ammann, S. Dannenmann, L. Vulliet (eds.). Rotterdam: Taylor and Francis / Balkema, London, 101- 108 p., 2006.

55. Pocinho, M.: Metodologia de Investigação e comunicação do conhecimento científico. Lisboa: Lidel, 2012.

56. Poortinga, W., Bronstering, K., Lannon, S.: Awareness and perceptions of the risks of exposure to indoor radon: A population based approach to evaluate a radon awareness and testing campaign in England and Wales, Risk Anal., 31, 1800-1812, 2011.

57. Renn, O., Burns, W., Kasperson, J., Kasperson, R., Slovic, P.: The Social Amplification of Risk: Theoretical Foundations and Empirical Applications. Journal of Social Issues, 48: 137-160, 1992. 
Nat. Hazards Earth Syst. Sci. Discuss., https://doi.org/10.5194/nhess-2018-312

Manuscript under review for journal Nat. Hazards Earth Syst. Sci.

Discussion started: 27 November 2018

(c) Author(s) 2018. CC BY 4.0 License.

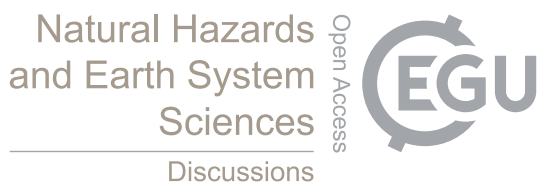

58. Renn, O., Rohrmann, B.: Cross-Cultural Risk Perception. A Survey of Empirical Studies. Risk, Governance and Society, Elsevier.

59. Renn, O.: Three decades of risk research: Accomplishments and new challenges. Journal of Risk Research, 1 (1): 49-71,1998.

5

60. Rory, A., Walshe, D., Chang, S., Adam, B., Joelle, A.: Perceptions of adaptation, resilience and climate knowledge in the Pacific: The cases of Samoa, Fiji and Vanuatu, International Journal of Climate Change Strategies and Management. https://doi.org/10.1108/ IJCCSM-03-2017-0060, 2017.

61. Salvati, P., Bianchi, C., Fiorucci, F., Giostrella, P., Marchesini, I., and Guzzetti, F.: Perception of flood and landslide risk in Italy: a preliminary analysis, Nat. Hazards Earth Syst. Sci., 14, 2589-2603, 2014.

62. Schumm: Erroneous perception of fluvial hazards, Geomorphology, 10, p.129-138, 1994.

63. Siegrist, M., Keller, C., Kiers, A.: A New Look at the Psychometric Paradigm of Perception of Hazards, Risk Analysis, 25: 211-222, 2005.

64. Siegrist, M. Gutscher, H.: Flooding Risks: A Comparison of Lay People's Perceptions and Expert's Assessments in Switzerland, Risk Analysis, 26: 971-979, 2006.

65. Sims, J. \& Baumann, D.: Educational programs and human response to natural hazards. Environment and Behavior, 15(2), 165-189 p., 1983.

66. Slovic P.: The Perception of Risk, Earthscan, 2000.

67. Slovic, P., Kraus, N., Covello, V. T.: What Should We Know About Making Risk Comparisons?, Risk Analysis, 10: 389-392, 1990

68. Slovic, P., Monahan, J., MacGregor, D.: Violence risk assessment and risk communication: The effects of using actual cases, providing instructions, and employing probability vs. frequency formats, Law and Human Behavior, 24(3), 271-296, 2000.

69. Slovic, P.: Perception of risk. Science, 236, 280-285, 1987.

70. Slovic, P.: The Psychology of Risk. Saúde Soc. São Paulo, v.19, n.4, p.731-747, 2010.

71. Smith, K. \& Petley, D.: Environmental Hazards, Routledge, 2009.

72. Soane, E., Dewberry, C., Narendran, S.: The role of perceived costs and perceived benefits in the relationship between personality and risk-related choices. Journal of risk research, 13 (3). pp. 303-318, 2010.

73. Terpstra, T.: Flood preparedness: thoughts, feelings and intentions of the Dutch public. Thesis, University of Twente, 2010.

74. Tierney K.: Toward a critical sociology of risk. Sociol. Forum, 14(2):215-42, 1999.

75. Tierney, K.: Sociology's Unique contributions to the study of Risk, Disaster Research Center, Preliminary Paper 204, 1994.

76. Botzen, W., Aerts, J., Van Den Bergh, C.: Dependence of flood risk perceptions on socioeconomic and objective risk factors, Water Resour. Res. 45, 2009. doi:10.1029/2009WR007743 
Nat. Hazards Earth Syst. Sci. Discuss., https://doi.org/10.5194/nhess-2018-312

Manuscript under review for journal Nat. Hazards Earth Syst. Sci.

Discussion started: 27 November 2018

(c) Author(s) 2018. CC BY 4.0 License.

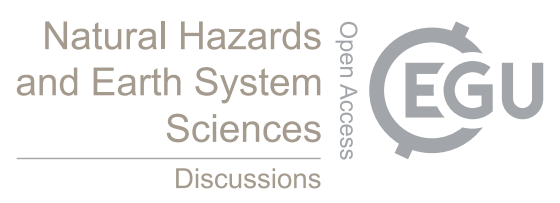

(c) (i)

77. Wachinger, G., Renn, O.: Risk perception and natural hazards. Cap.Haz.Net. Social Capacity Building for Natural Hazards Toward More Resilient Societies, 2010.

78. Wachinger, G., Renn, O., Begg, C., Kuhlicke, C.: The Risk Perception Paradox - Implications for Governance and Communication of Natural Hazards. Risk Analysis, 33: 1049-1065, 2013.

79. Wagner, K.: Mental Models of Flash Floods and Landslides. Risk Analysis, 27: 671-682, 2007.

80. Weichselgartner, J.: Disaster mitigation: the concept of vulnerability revisited, Disaster Prev. Manag.,10(2):85-94. 2001.

81. Weinstein, N.: Effects of personal experience on self-protective behaviour, Psychol. Bull., 105(1):31-50, 1989.

82. White, G.: Human adjustments to floods, Unpublished PhD, Department of Geography, University of Chicago, 1942.

83. Wilson, C.: Education and risk. In Handmer, J., Penning-Rowsell, E.: (Eds), Hazards and the communication of risk, Gower, England, 1990.

84. Young, E.: Dealing with hazards and disaster: risk perception and community participation in management. Presented at a workshop: "Putting the community into emergency risk management", Australian Emergency Management Institute, 1997. 